\title{
ANALISIS KONSEP FISIKA ENERGI MEKANIK PADA PERMAINAN TRADISIONAL EGRANG SEBAGAI BAHAN PEMBELAJARAN FISIKA
}

\author{
Rumiati, Rif'ati Dina Handayani, I Ketut Mahardika \\ Pendidikan Fisika, Fakultas Keguruan dan Ilmu Pendidikan, Universitas Jember \\ Email: rumiati.fkip@gmail.com
}

Diterima: 26 Februari 2021. Direvisi: 18 Agustus 2021 Disetujui: 30 September 2021.

\begin{abstract}
Abstrak
Indonesia merupakan negara yang kaya akan kearifan lokal, namun mulai pudar seiring dengan perkembangan teknologi. Pelestarian kearifan lokal sangat diperlukan salah satunya dengan mengintegrasikan ke dalam pembelajaran fisika. Salah satu kearifan lokal yang terdapat konsep fisika adalah permainan tradisional Egrang. Tujuan penelitian yaitu menganalisis konsep fisika energi mekanik pada permainan tradisional Egrang. Penelitian ini menggunakan metode penelitian deskriptif kualitatif dengan pendekatan etnografi. Pengambilan data dilakukan melalui observasi, wawancara dan dokumentasi secara langsung di lapangan. Penelitian ini memberikan gambaran bahwa dalam permainan tradisional Egrang terdapat konsep fisika energi mekanik yang dapat menghubungkan antara sains modern dengan etnosains. Energi mekanik merupakan penjumlahan energi kinetik dan energi potensial suatu benda untuk melakukan kerja. Konsep energi kinetik terdapat pada gerak Egrang, sedangkan energi potensial terdapat pada ketinggian pijakan dan posisi terangkatnya Egrang. Hasil penelitian ini diharapkan dapat menjelaskan etnosains pada permainan tradisional Egrang dan bisa digunakan sebagai bahan pembelajaran fisika.
\end{abstract}

Kata Kunci: Etnosains, Permainan Tradisional, Egrang, Energi Mekanik.

\begin{abstract}
Indonesia is a country rich in local wisdom, but it is fading along with technological development. The preservation of local wisdom is vital, one of which is by integrating into the study of physics. One of the local knowledge that there is a concept of physics is the traditional Egrang games. The study's purpose was to analyze mechanical energy physics in the traditional Egrang games. This research uses a descriptive qualitative research method with an ethnographic approach. Data collection is by observation, interview, and documentation directly in the field. This research gives an idea that in the traditional game of Egrang, there is a concept of mechanical energy physics that can connect modern science with ethnoscience. Mechanical energy is the sum of kinetic energy and an object's potential energy to do the work. The concept of kinetic energy is found in the motion of Egrang, while the potential energy is at the height of the footing and the elevated position of Egrang games. This study's results are expected to explain ethnoscience, the traditional Egrang games, and learning material for physics.

Keywords: Ethnoscience, Traditional Games, Egrang, Mechanical Energy.
\end{abstract}


Rumiati., Handayani.,\& Mahardika. - Analisis Konsep Fisika ...

\section{PENDAHULUAN}

Kearifan lokal adalah cara dan praktik yang dikembangkan oleh sekelompok masyarakat yang berasal dari pemahaman mendalam terhadap lingkungan setempat secara turun temurun (Deskarina \& Atiqah, 2020). Seiring dengan perkembangan zaman dan teknologi kearifan lokal mulai pudar dan beresiko hilang karena dianggap berbeda antara ilmu pengetahuan lokal dan ilmu sains. Padahal kearifan lokal terdapat pelajaran-pelajaran yang dapat diteladani dan dikembangkan ke dalam pembelajaran fisika di sekolah (Hariastuti et al, 2020). Salah satu kearifan lokal yang dapat diintegrasikan ke dalam pembelajaran fisika di sekolah adalah permainan tradisional.

Permainan tradisional merupakan salah satu unsur budaya lokal yang sering dijumpai dari berbagai penjuru nusantara dan biasa terdapat dalam masyarakat pedesaan. Permainan tradisional tidak hanya berpusat pada main-main saja, melainkan dapat memberikan pengaruh besar pada perkembangan kejiwaan, sifat dan kehidupan sosial (Hariastuti et al, 2020). Hal ini karena dalam permainan tradisional mengandung unsur sportivitas, kecermatan, kejujuran, kelincahan, dan kemampuan bekerja dalam kelompok.

Permainan tradisional memiliki banyak manfaat yaitu dapat melatih kreativitas anak, dapat mengontrol emosional, kecerdasan sosial, mendekatkan anak-anak pada alam, dapat mengembangkan kemampuan motorik anak, bermanfaat melatih kesehatan, mengasah kepekaan anak dan lain sebagainya (Hariastuti et al, 2020). Selain banyak manfaat yang ada pada permainan tradisional, ternyata juga terdapat konsep-konsep dalam pembelajaran umum seperti matematika, IPA, IPS, dan bahasa daerah. Konsep-konsep yang terdapat di dalam permainan tradisional dapat mempermudah guru dalam menyampaikan pembelajaran kepada perserta didik. Integrasi ini dapat digunakan dalam pembelajaran maka perlu mengkaji filosofi, teknik permainan dan aturan yang berlaku terlebih dahulu.

Fakta pembelajaran sekarang tidak sejalan dengan tujuan kurikulum 2013 


\section{Rumiati., Handayani.,\& Mahardika. - Analisis Konsep Fisika ...}

yang menggunakan pendekatan saintifik (Makhmudah et al., 2019). Pendekatan saintifik mengharuskan peserta didik memahami sains dari lingkungan sekitar. Namun, guru hanya memberikan contoh-contoh umum atau bahkan jarang diketahui peserta didik dan pembelajaran yang dilakukan hanya bersifat hafalan (Rosita et al, 2019). Akibatnya peserta didik kurang peka terhadap peristiwa yang sedang terjadi di lingkungan sekitarnya, padahal memiliki kaitan dengan ilmu fisika.

Ilmu fisika merupakan bagian dari ilmu pengetahuan alam yang menjelaskan fenomena teramati didasarkan pada pemikiran rasional, pengalaman manusia, dan eksperimen. Fisika dapat dinyatakan sangat dekat dengan kehidupan sehari-hari. Kenyataan bahwa permainan tradisional mengandung banyak konsep fisika yang dapat dianalisis dan sesuai dengan standar kompetensi lulusan (SKL), maka perlu mengintegrasikan ke dalam pembelajaran fisika di sekolah.

Permainan tradisional Egrang merupakan salah satu dari banyaknya permainan tradisional di Indonesia yang perlu dilestarikan. Permainan tradisional Egrang merupakan permainan yang berasal dari Jawa Barat dan biasa ditemui di daerah perdesaan (Supriyono, 2018). Permainan tradisional Egrang mengandung nilai keuletan, sportivitas dan kerja keras dalam memainkannya (Hariastuti et al, 2020). Selain itu pada permainan tradisional Egrang terdapat konsepkonsep fisika yang dapat diintegrasikan ke dalam pembelajaran fisika, salah satunya adalah energi mekanik.

Berdasarkan uraian di atas maka tujuan penelitian ini adalah menganalisis konsep fisika energi mekanik pada permainan tradisional Egrang.

\section{METODE}

\begin{tabular}{lcr}
\multicolumn{1}{c}{ Jenis } & penelitian ini & adalah \\
deskriptif & kualitatif & dengan \\
pendekatan & etnografi. & Pendekatan \\
etnografi & bertujuan & untuk
\end{tabular}
mendeskripsikan dan analisis kebudayaan berdasarkan penelitian lapangan yang intensif (Bungin, 2012). Pendekatan etnografi pada penelitian ini digunakan untuk 
Rumiati., Handayani.,\& Mahardika. - Analisis Konsep Fisika ...

menggambarkan, menjelaskan dan

Adapun Gambar 1 merupakan alur menganalisis konsep-konsep fisika desain penelitian.

yang terdapat pada permainan

tradisional Egrang.

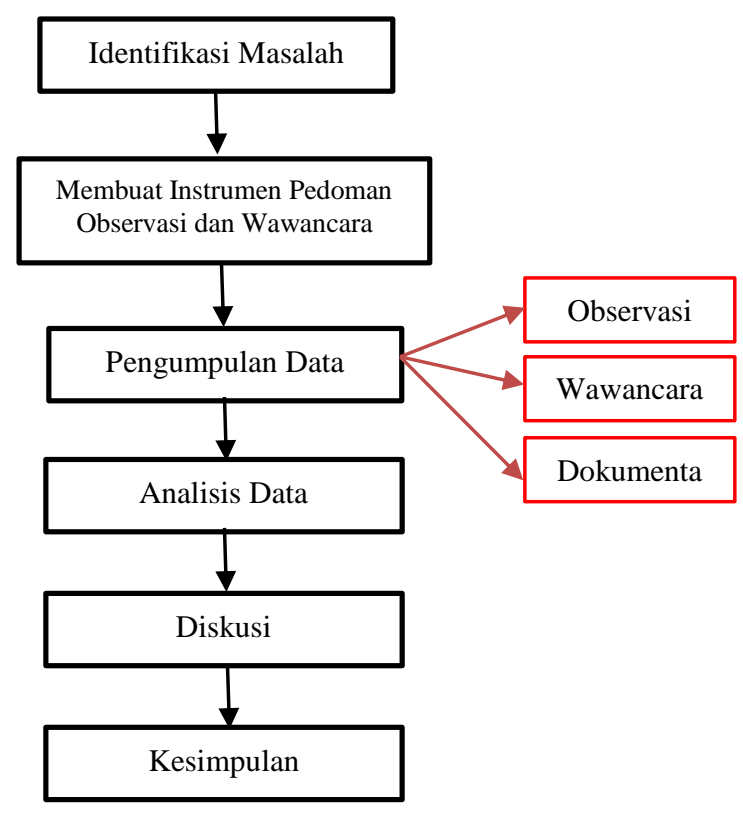

Gambar 1. Desain Penelitian

Metode pengumpulan data lengan pemain Egrang dan massa dilakukan dengan observasi, pemain Egrang.

wawancara dan dokumentasi di Kegiatan wawancara dilakukan wilayah Tegal Boto Lor, Sumbersari untuk mendapatkan informasi terkait Kabupaten Jember, Jawa Timur. hal-hal yang lebih spefisik berkaitan Pengambilan data observasi dilakukan dengan etnofisika pada permainan secara langsung di lapangan dengan tradisional Egrang yang dilakukan mengamati permainan tradisional kepada pemain Egrang. Pemain Egrang yang dilakukan oleh 3 orang Egrang dipilih karena mereka masih pemain Egrang sesuai dengan mempertahankan kearifan lokal dan variabel penelitian. Variabel yang dapat menjelaskan fenomena pada mempengaruhi penelitian ini antara permainan Egrang. Serta kegiatan lain tinggi pijakan Egrang, posisi dokumentasi dilakukan selama 
Rumiati., Handayani.,\& Mahardika. - Analisis Konsep Fisika ...

observasi yang digunakan sebagai data visual penelitian.

Instrumen penelitian yang digunakan dalam penelitian ini adalah pedoman observasi dan pedoman wawancara. Pedoman observasi berisi kisi-kisi aktivitas yang akan diamati dalam permainan tradisional Egrang dan pedoman wawancara berisi kumpulan pertanyaan yang akan ditanyakan pewawancara kepada narasumber.

Data yang terkumpul kemudian dilakukan analisis data dengan langkah; (1) mereduksi data hasil observasi dan wawancara; (2) menyajikan data dalam bentuk teks deskriptif; dan (3) menarik kesimpulan. Wawancara dilakukan menggunakan bahasa Indonesia dan ditranskrip menggunakan kode wawancara yaitu huruf kapital $\mathrm{P}$ untuk peneliti dan $S$ untuk subjek. Setelah menuliskan kode selanjutnya diikuti dengan empat digit angka yang menyatakan urutan percakapan.

\section{HASIL DAN PEMBAHASAN}

Permainan tradisional merupakan warisan yang bersifat turun temurun, di dalamnya mengandung nilai edukasi dan kultur budaya Indonesia (Rosramadhana et al, 2020). Egrang merupakan permainan yang menggunakan bambu atau kayu. Permainan ini sudah ada sejak zaman belanda dan cukup terkenal ditahun 1900-an dan telah menyebar di berbagai wilayah di Indonesia dengan nama yang berbeda-beda.

Nama Egrang di Bengkulu disebut sepatu Bambu, di Sumatera dinamakan Tengkak-tengkak, Lampung dinamakan Terompah Pancung, Jawa Tengah di namakan Jangkungan atau Egrang, di Kalimantan Selatan dinamakan Batungkau, di Sulawesi Tengah dinamakan Tilako, di Batak Toba dinamakan Marjalengkat, di Sunda dinamakan Jajangkungan yang artinya tinggi (Malik, 2019) dan lain sebagainya.

Penelitian ini bertujuan untuk mengetahui konsep fisika pada permainan tradisional Egrang khususnya energi mekanik. Hasil penelitian yang telah dilakukan terdapat konsep fisika energi mekanik pada permainan tradisional Egrang yang dapat dijadikan sebagai bahan pembelajaran fisika. Interpretasi 
Rumiati., Handayani.,\& Mahardika. - Analisis Konsep Fisika ...

responden dari dua narasumber yaitu AN (S2), dan HF (S3) akan disajikan dan dibandingkan dengan konsep fisika terkait. Penelitian ini mengungkapkan pengetahuan lokal dengan pengetahuan sains modern.
Permainan tradisional Egrang berasal dari Jawa Barat (daerah Sunda), dan kemudian banyak diminati oleh daerah lain di Jawa (Supriyono, 2018). Karena permainan ini seru, menarik dan penuh tantangan dalam memainkannya.

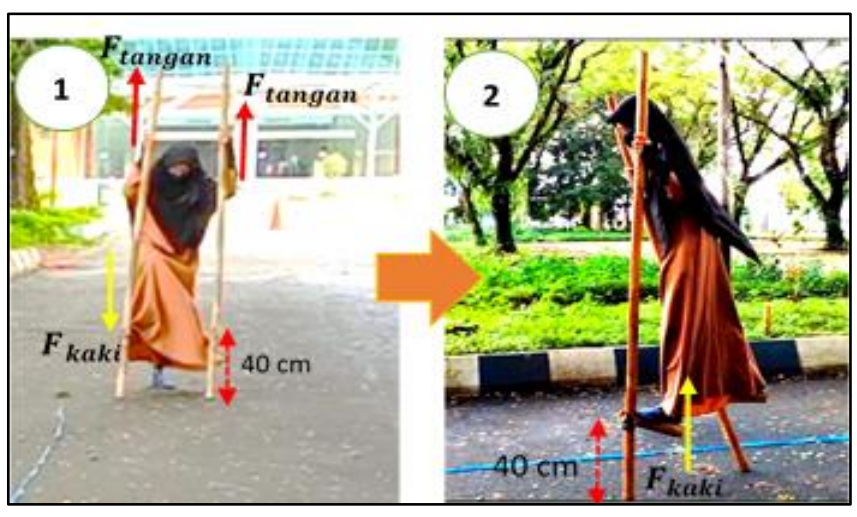

Gambar 2. Permainan Tradisional Egrang

Alat permainan ini menggunakan sepasang bambu yang berbentuk seperti tongkat dan terdapat tumpuan kaki. Bambu panjang yang digunakan berukuran panjang 2 meter, diameter bambu $4 \mathrm{~cm}$, dan tinggi pijakan berbeda $(30 \mathrm{~cm}, 40 \mathrm{~cm}$, dan $50 \mathrm{~cm})$. Permainan ini memerlukan kekuatan otot tungkai dan tangan yang digunakan untuk berjalan. Berdasarkan observasi dan wawancara yang dilakukan oleh S3, cara dan langkah dalam melakukan permainan tradisional Egrang adalah sebagai berikut:

a. Menyiapkan Egrang

b. Menegakkan Egrang tepat di depan pemain dan

c. posisi Egrang sedikit condong ke depan

d. Pegang Egrang sesuai dengan lengan pemain yang tepat.

e. Angkat salah satu kaki di atas pijakan Egrang, dan diikuti oleh kaki berikutnya.

f. Atur keseimbangan dan mulai berjalan sampai batas akhir 
Rumiati., Handayani.,\& Mahardika. - Analisis Konsep Fisika ...

g. Jika merasa akan terjatuh, maka turunkan kaki di antara Egrang.

h. Usahakan bermain di tempat yang luas

Pengamatan lapangan pada dapat melihat teknik dan fenomena secara langsung.

Hasil penelitian yang dapat ditulis dalam Tabel 1 berikut.

permainan tradisional Egrang, peneliti

Tabel 1. Gerakan permainan Egrang

\begin{tabular}{|c|c|c|}
\hline Konsep Fisika & Gerakan & Keterangan \\
\hline \multirow[t]{8}{*}{ Energi Kinetik } & Mengangkat/naik Egrang & \multirow{8}{*}{$\begin{array}{l}\text { Terdapat gaya yang } \\
\text { menyebabkan Permainan } \\
\text { Egrang bergerak/berjalan } \\
\text { dengan kecepatan tertentu }\end{array}$} \\
\hline & Memegang Egrang & \\
\hline & Mendorong Egrang & \\
\hline & Memutar gerakan/belok & \\
\hline & Berjalan di atas Egrang & \\
\hline & Menarik lengan menuju tubuh & \\
\hline & Menekuk lengan, kaki dan tubuh & \\
\hline & Massa pemain Egrang & \\
\hline \multirow[t]{4}{*}{ Energi Potensial } & Tinggi pijakan Egrang & \multirow{4}{*}{$\begin{array}{lr}\text { Terdapat } & \text { energi } \\
\text { karena } & \text { keadaan } \\
\text { kedudukan } & \text { atau } \\
\text { tertentu. } & \end{array}$} \\
\hline & Mengangkat Egrang & \\
\hline & Melangkah di atas Egrang & \\
\hline & Mengangkat paha menjauh dari tubuh & \\
\hline
\end{tabular}

Permainan Egrang yang sedang berlangsung berkaitan erat dengan konsep fisika usaha dan energi. Usaha merupakan kerja yang dilakukan oleh pemain untuk dapat naik ke pijakan Egrang dan kerja untuk memindahkan Egrang dari posisi awal ke posisi akhir. Energi tersebut adalah energi mekanik atau penjumlahan energi kinetik dan energi potensial.

\section{a. Energi Kinetik}

Suatu benda yang bergerak maka terdapat energi di dalamnya
(Abdullah, 2016). Gerak benda disebabkan oleh gaya yang bekerja. Energi yang dimiliki oleh suatu benda yang bergerak adalah energi kinetik. Besar kecilnya energi kinetik ditunjukkan dengan gaya yang diberikan oleh pemain Egrang yang diinterpretasikan pada kecepatan Egrang.

Responden ditanya tentang posisi lengan yang tepat saat memegang lengan Egrang, yang ditunjukkan pada Tabel 2. 
Rumiati., Handayani.,\& Mahardika. - Analisis Konsep Fisika ...

Tabel 2. Transkrip wawancara tentang posisi lengan pemain Egrang

\begin{tabular}{cl}
\hline Kode & \multicolumn{1}{c}{ Pertanyaan/Tanggapan } \\
\hline P2014 & .bagaimana sih perbedaan dari tiga bentuk posisi tangan ini atau bentuk sudut \\
& yang berbeda ini, lebih ringan, lebih mudah dan lebih enakan mana saat \\
& memainkan permainan Egrang itu? \\
\hline S2014 & Kalau saya ngerasanya itu, kalau dia makin kebawah berarti kan sudutnya \\
& semakin besar kan ya. Itu agak susah juga, soalnya kayak bungkuk gitu, jadi \\
& ngangkatnya itu jadi lebih berat juga. Tapi kalau terlalu ke atas juga, juga gak \\
& enak juga. Soalnya akhirnya terus tangannya jadi terlalu tinggi, jadi \\
& ngangkatnya berat juga. Jadi pasnya ya yang di tengah sih, yang 90 derajat itu. \\
\hline
\end{tabular}

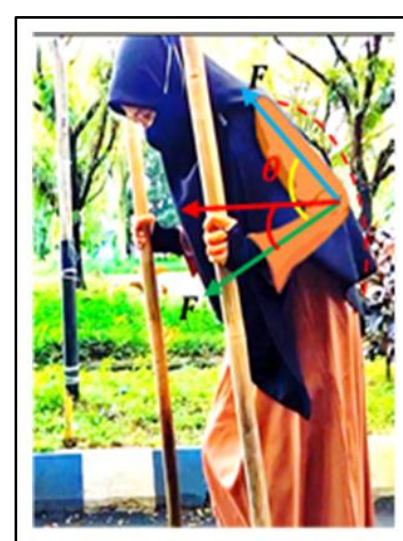

(a)

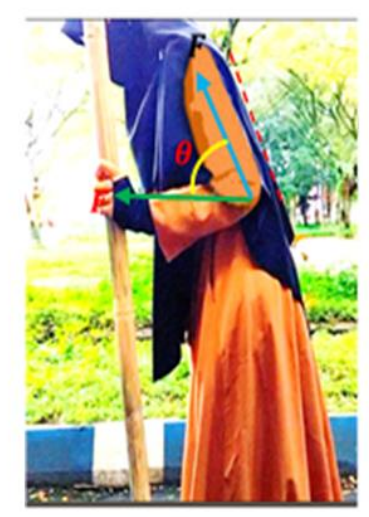

(b)

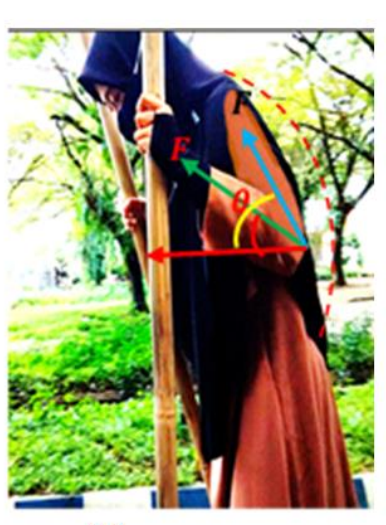

(c)

Gambar 3. Perbedaan Posisi Lengan Pemain Egrang oleh Pemain Bermassa 44 kg
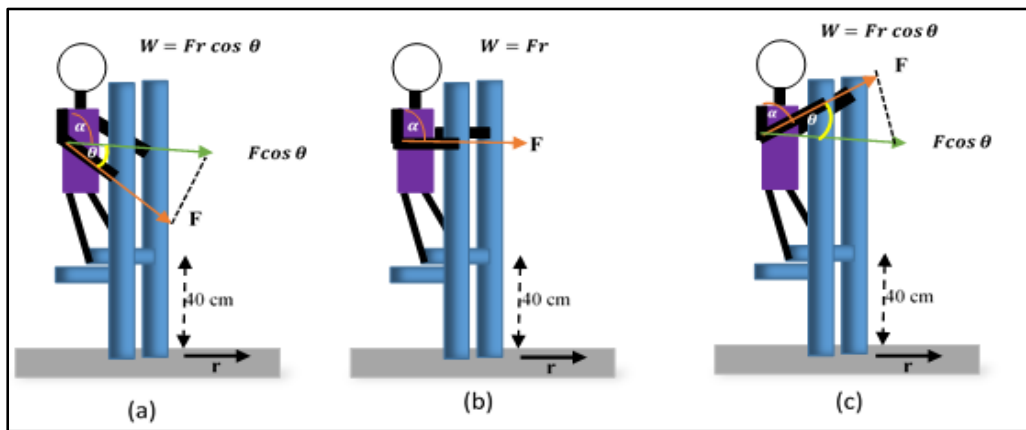

Gambar 4. Ilustrasi gaya Egrang

Kutipan di atas menunjukkan bahwa responden tahu dari pengalaman bermain Egrang bahwa saat melakukan permainan, posisi lengan yang tepat adalah tegak lurus dengan lengan Egrang. Sedangkan jika posisi lengan pemain terlalu ke bawah atau ke atas, maka menyebabkan kecepatan Egrang kecil. Hal ini menunjukkan bahwa gaya yang diberikan oleh pemain Egrang memiliki pengaruh terhadap energi kinetik benda. 
Gambar 3 (a) adalah posisi lengan bawah pemain yang cenderung ke bawah yaitu membentuk sudut kurang lebih 115 derajat apabila diukur antara lengan atas dengan lengan bawahnya dan membentuk sudut $\theta$ terhadap gaya yang diberikan. Posisi tersebut menghasilkan gaya sebesar $F \cos \theta$. Gambar 3 (b) adalah posisi lengan bawah pemain lurus ke depan, kondisi ini membentuk sudut 90 derajat apabila diukur antara lengan atas dan lengan bawah. Besar gaya yang bekerja pada posisi ini adalah $F$. Gambar 3 (c) adalah posisi lengan bawah pemain ke atas atau membentuk sudut kurang lebih 45 derajat apabila diukur antara lengan atas dengan lengan bawah pemain dan membentuk sudut $\theta$ terhadap gaya yang diberikan. Posisi ini menghasilkan gaya yang bekerja sebesar $F \cos \theta$. Besar gaya terbesar pada permainan ini adalah pada posisi lengan lurus ke depan, sedangkan saat posisi lengan condong ke bawah ataupun ke atas gaya yang diberikan lebih kecil. Besar kecilnya gaya pemain Egrang mempengaruhi nilai usaha $W$ dan mempengaruhi energi kinetik.
Hasil observasi menunjukkan bahwa pada posisi lengan yang lurus dapat melangkah dengan lebar sehingga cepat sampai ke titik akhir $\left(E_{k}=14,648 J\right)$. Sedangkan, pada posisi lengan ke bawah melangkah dengan lebar kaki kecil $\left(E_{k}=\right.$ 28,291J) dan membutuhkan banyak langkah untuk mencapai finis dan saat lengan ke atas lebar langkah saat berjalan tidak terlalu sempit $\left(E_{k}=\right.$ 16,805).

Besar kecilnya gaya di atas terbukti mempengaruhi laju permainan Egrang yang sedang berlangsung. Pengaruh kelajuan benda terhadap energi kinetik dapat dilihat pada perbedaan ketinggian pijakan Egrang. Masing-masing tinggi pijakan Egrang memiliki pengaruh terhadap kenyaman pemain dan laju yang dihasilkan. Pada penelitian (Tabel 3) penelitian dengan tinggi pijakan Egrang yang berbeda oleh pemain Egrang yang bermassa $44 \mathrm{~kg}$ terdapat energi potensial yang mempengaruhi kelajuan Egrang. Hal ini berarti terdapat energi kinetik yang dipengaruhi oleh kelajuan tersebut. Hasil analisis pada Tabel 3 menunjukkan bahwa pada tinggi 
Rumiati., Handayani.,\& Mahardika. - Analisis Konsep Fisika ...

pijakan $50 \mathrm{~cm}$ dengan kelajuan 0,78 $\mathrm{m} / \mathrm{s}$, besar energi kinetiknya adalah 13,385 J. Besar energi kinetik pada tinggi pijakan Egrang $40 \mathrm{~cm}$ dengan kelajuan 0,75 adalah $12,375 \mathrm{~J}$ dan

Tabel 3. Hasil Percobaan Permainan Egrang dengan Sudut Berbeda oleh Massa 44

\begin{tabular}{cccc}
\multicolumn{4}{c}{$\mathrm{kg}$} \\
\hline Posisi Lengan & $\bar{t}(s)$ & $v(\mathrm{~m} / \mathrm{s})$ & $E k(\mathrm{~J})$ \\
\hline Ke Bawah & 14,18 & 1,134 & 28,291 \\
Lurus & 10,20 & 0,816 & 14,648 \\
Ke Atas & 10,93 & 0,874 & 16,805 \\
\hline
\end{tabular}

Energi kinetik juga dipengaruhi oleh massa benda. Hasil analisis pada Tabel 4 menunjukkan bahwa nilai energi kinetik terbesar terdapat pada massa pemain $48 \mathrm{~kg}$ dengan kelajuan $0,836 \mathrm{~m} / \mathrm{s}$ yaitu sebesar $15,375 \mathrm{~J}$. Kemudian pada pemain bermassa 44 $\mathrm{kg}$ dengan kelajuan $0,598 \mathrm{~m} / \mathrm{s}$ sebesar 7, $867 \mathrm{~J}$ dan terakhir pada pemain yang bermassa $52 \mathrm{~kg}$ dengan kelajuan

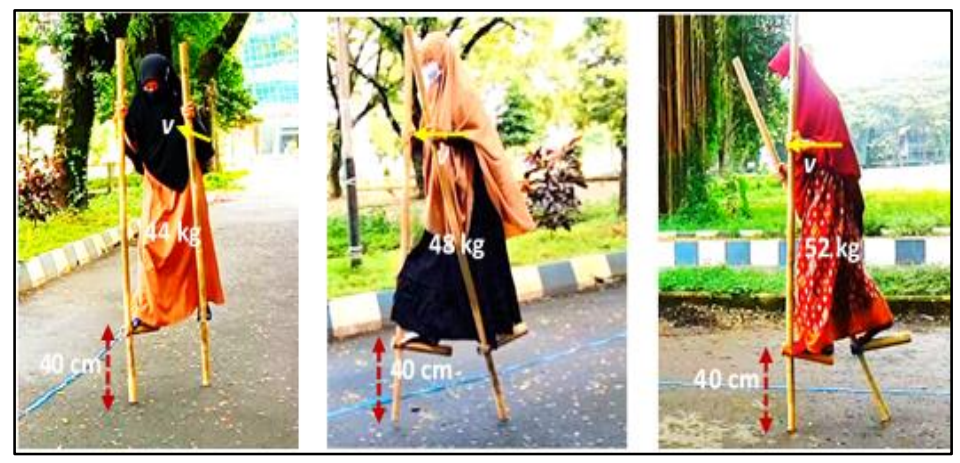

Gambar 5. Perbedaan Massa Pemain Egrang

Tabel 4. Hasil Percobaan Permainan Egrang dengan Massa Berbeda

\begin{tabular}{ccccc}
\hline Massa $(\mathrm{kg})$ & $\bar{t}(s)$ & $v(\mathrm{~m} / \mathrm{s})$ & $E_{K}(s)$ & $E_{P}(s)$ \\
\hline 44 & 10,46 & 0,836 & 15,375 & 172,48 \\
48 & 7,47 & 0,598 & 7,867 & 188,16 \\
52 & 11,22 & 0,898 & 17,741 & 203,84 \\
\hline
\end{tabular}


Rumiati., Handayani.,\& Mahardika. - Analisis Konsep Fisika ...

Gerak benda yang semakin cepat kecepatan tertentu dan pada penelitian menyebabkan energi kinetik semakin besar. Secara matematis energi Surabidin (2019) bahwa semakin kinetik dirumuskan:

$$
E_{k}=\frac{1}{2} m v^{2}
$$

keterangan :

$E_{k}$ : Energi kinetik (J)

$m$ : massa benda $(\mathrm{kg})$

$v$ : kecepatan benda $(\mathrm{m} / \mathrm{s})$

Penelitian konsep energi kinetik yang telah dipaparkan di atas sesuai dengan penelitian Kalhor et al (2020) untuk memperbesar energi kinetik maka membutuhkan usaha partikel dan

besar energi kinetik yang dihasilkan. Energi kinetik dalam ilmu fisika, bergantung pada massa dan kecepatan benda.

b. Energi Potensial

Energi potensial merupakan energi yang tersimpan di dalam benda karena kedudukan atau posisinya (Abdullah, 2016). Selain dipengaruhi oleh kedudukannya, energi potensial dipengaruhi pula oleh gaya gravitasi bumi.

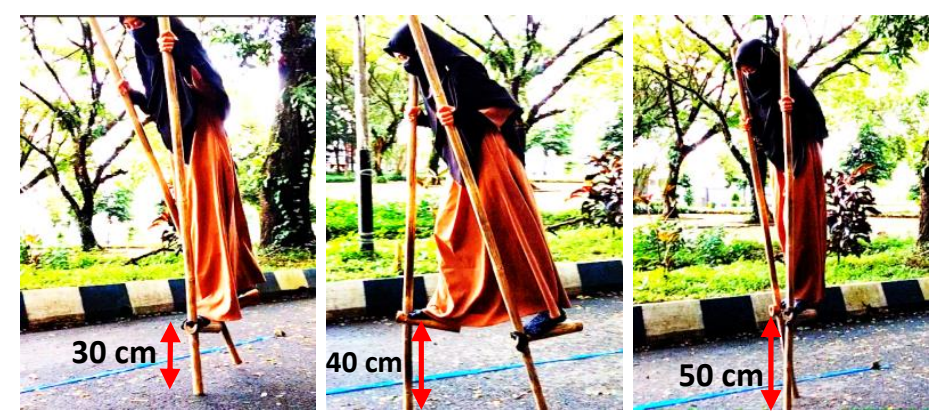

Gambar 6. Perbedaan Tinggi pijakan Egrang oleh Massa 44 kg

Tabel 5. Hasil Wawancara Ketinggian Pijakan Egrang

\begin{tabular}{cl}
\hline Kode & \multicolumn{1}{c}{ Pertanyaan/Tanggapan } \\
\hline P2007 & $\begin{array}{l}\text {....Apakah yang mbak rasakan saat memainkan Egrang ketika hmmm apa } \\
\text { ya, pada ketinggian yang berbeda-beda itu?... }\end{array}$ \\
\hline S2007 & $\begin{array}{l}\text { Kalau menurut saya lebih enakan ya, lebih seimbang, lebih terasa ringan } \\
\text { juga yang lebih tinggi. Cuma kalau naikknya ya lebih susah, lebih susah, } \\
\\
\\
\text { makin tinggi ya makin susah tapi kalau ketika sudah jalan, itu sebenarnya } \\
\text { makin tinggi makin enak sebenarnya kalau semakin tinggi pijkannya. }\end{array}$ \\
\hline
\end{tabular}

Kutipan di atas menunjukkan bahwa responden mengetahui beradasarkan permainan Egrang yang dilakukan bahwa semakin tinggi pijakan Egrang 
maka lebih mudah dan ringan saat memainkannya.

Observasi ini membuktikan semakin tinggi pijakan Egrang maka energi potensial semakin besar, karena semakin besar jarak antara pijakan Egrang dengan permukaan bumi. Hasil analisis energi potensial pada ketinggian pijakan Egrang yang berbeda yaitu $30 \mathrm{~cm}, 40 \mathrm{~cm}$, dan 50 cm oleh pemain Egrang yang bermassa $44 \mathrm{~kg}$ (Tabel 4), dihasilkan nilai energi potensial yang berbeda. Energi potensial pada tinggi pijakan $30 \mathrm{~cm}$ sebesar 129,36 J, pada tinggi pijakan $40 \mathrm{~cm}$ sebesar 172,48 J, dan pada tinggi pijakan $50 \mathrm{~cm}$ sebesar 215,60 J. Massa pemain Egrang merupakan salah satu yang mempengaruhi besar energi potensial, dalam penelitian ini diperoleh besar energi potensial pada massa $44 \mathrm{~kg}$ sebesar 172,48 J, massa 48 sebesar 188,16 J, dan massa $52 \mathrm{~kg}$ sebesar 203,84 J. Sehingga semakin besar massa benda maka energi potensial yang terdapat pada benda itu juga semakin besar.

Nilai energi potensial tersebut sesuai dengan konsep fisika energi potensial bahwa besarnya energi potensial bergantung pada tinggi benda dari permukaan bumi. Sehingga sesuai dengan penelitian yang dilakukan oleh Maison (2020) yaitu pada identifikasi materi usaha dan energi, mengatakan bahwa energi potensial dihasilkan oleh suatu gaya yang bergantung pada kedudukan atau posisi sebuah benda yang relatif terhadap lingkungannya dan Lestari (2020) mengatakan bahwa semakin tinggi posisi suatu benda maka akan semakin besar energi potensial pada benda tersebut.

Secara matematis energi potensial sesuai persamaan (3):

$$
E p=m g h
$$

dengan

$E_{p}$ : Energi potensial (J)

$m$ : massa benda $(\mathrm{kg})$

$g:$ percepatan gravitasi $\left(\mathrm{m} / \mathrm{s}^{2}\right)$

$h:$ ketinggian (m)

\section{c. Energi Mekanik}

Energi mekanik merupakan penjumlahan energi kinetik dan potensial suatu benda untuk melakukan kerja. Permainan tradisional Egrang yang dilakukan jelas bahwa terdapat energi mekanik sesuai yang telah diuraikan di atas. 
Terlihat saat pemain Egrang memulai permainan sampai dengan selesai permainannya. Secara matematis energi mekanik sesuai persamaan (4):

$$
E M=E K+E P=\frac{1}{2} m v^{2}+m g h(4)
$$

Studi pengetahuan lokal terkait konsep energi mekanik pada permainan tradisional Egrang memiliki potensi untuk meningkatkan pengetahuan dan melestarikan nilainilai kearifan lokal di Indonesia. Apabila ditinjau dari perspektif pendidikan, identifikasi pengetahuan lokal terkait konsep fisika sesuai dengan kurikulum 2013 dan dapat digunakan oleh pendidik, orang tua, serta masyarakat untuk bahan pembelajaran fisika di sekolah. Pembelajaran di sekolah yang mengintegrasikan pengetahuan lokal ke dalam pengetahuan modern dapat memberikan dampak positif terhadap siswa karena dapat menghubungan antara konsep fisika dengan kehidupan sehari-hari.

Materi pelajaran hakikatnya berisi pesan-pesan yang ingin disampaikan pada peserta didik untuk mencapai tujuan pembelajaran (Martawijaya, 2014). Pesan tersebut dapat berupa ide, konsep, data atau fakta, tulisan, gambar, simbol dan lain sebagainya. Tidak semua pesan tersebut dapat diterima oleh peserta didik, maka menurut Sanjaya (2010) perlu memerhatikan beberapa kriteria yang harus diperhatikan. Pertama, Novelty yaitu jika pesan bersifat baru atau mutakhir. Kedua, Proximity yaitu pesan yang disampaikan harus sesuai dengan pengalaman sehari-hari peserta didik. Ketiga, Conflict yaitu pesan yang disajikan harus dikemas sedemikian rupa untuk menggugah emosi peserta didik. terakhir, Humor yaitu dikemas dalam bentuk lucu agar menarik. Berdasarkan poin kedua di atas, bahwa dalam menyampaikan materi sesuai dengan pengalaman sehari-hari peserta didik agar materi dapat diterima dengan baik. Sehingga bahan pembelajaran haruslah berbasis kearifan lokal daerahnya, salah satunya pada permainan tradisional Egrang.

Bahan pembelajaran berbasis kearifan lokal pada permainan tradisional Egang sesuai dengan penelitian yang dilakukan oleh Safitri et al (2018) dalam penelitiannya tentang pengembangan modul IPA berbasis kearifan lokal kopi pada 
Rumiati., Handayani.,\& Mahardika. - Analisis Konsep Fisika ...

materi usaha dan energi mengatakan bahwa modul tersebut efektif baik ditinjau dari aspek hasil belajar maupun aktivitas belajar siswa. Atabikrifki et al (2018) dalam penelitiannya tentang pengembangan buku siswa fisika berbasis kearifan lokal layak digunakan dan mudah dipahami oleh peserta didik. Serta oleh Hunaepi et al (2020) dalam penelitiannya tentang implementsi worksheet inkuiri terintegrasi kearifan lokal untuk meningkatkan keterampilan berpikir kritis mahasiswa. Penelitian tersebut membuktikan dapat meningkatkan kerampilan berpikir kritis pelajar dengan kategori sedang.

\section{KESIMPULAN DAN SARAN}

\section{Kesimpulan}

Hasil penelitian ini menunjukkan bahwa pada permainan tradisional Egrang terdapat konsep fisika energi mekanik. Permainan tradisional Egrang perlu dilestarikan dan dipertahankan keberadaannya. Salah satu cara untuk melestarikan adalah dengan menghubungkan antara pengetahuan lokal dan sains modern untuk diintegrasikan ke dalam pembelajaran fisika di sekolah.

\section{Saran}

Perlu dilakukan penelitian lebih lanjut terkait analisis konsep fisika pada permainan tradisional lainnya yang ada di Indonesia. Analisis tersebut dapat digunakan sebagai bahan pembelajaran fisika di sekolah.

\section{Ucapan Terima Kasih}

Penelitian ini didukung oleh kelompok riset Pendidikan Fisika, Universitas Jember. Kami ucapkan terima kasih atas dukungan dan bantuan kepada narasumber dan semua pihak yang terlibat dalam penelitian sehingga dapat berjalan dengan lancar.

\section{DAFTAR PUSTAKA}

Abdullah, M. (2016). Fisika Dasar I. Bandung: Institut Teknologi Bandung.

Atabikrifki., Martawijaya, MA \& Jasruddin. (2018). Pengembangan Buku Siswa Fisika Berbasis Kearifan Lokal (Maja Labo Dahu) di MAN 1 Kota Bima. Jurnal Sains dan Pendidikan Fisika. 14(3):8-14. http://10.35580/jspf.v14i3.9942

Bungin, B. (2012). Analisis Data Penelitian Kualitatif. Jakarta: PT Raja Grafindo Persada. 
Rumiati., Handayani.,\& Mahardika. - Analisis Konsep Fisika ...

Deskarina, R \& Atiqah A N. (2020). Potensi Kearifan Lokal Desa Bugisan Sebagai Upaya Pengembangan Daya Tarik Wisata Pendukung Kawasan Candi Plaosan. Jurnal Pariwisata dan Budaya.11(1): 41-49. http://10.31294/khi.v11i1.6906

Hariastuti, Retno $\mathrm{T}$ \& Laili, $\mathrm{P}$. (2020). Pengembangan Media "ITTR" Sebagai Latihan Relaksasi untuk Menurunkan Stres Belajar Siswa di SMAN 3 Sidoarjo. Jurnal BK UNESA. 11(5): 755-764.

Hunaepi, Firdaus L., Samsuri T., Susantini E., \& Raharjo. (2020). Implementsi Worksheet Inkuiri Terintegrasi Kearifan Lokal Untuk Meningkatkan Keterampilan Berpikir Kritis Mahasiswa. Jurnal Ilmiah Biologi. 8(1): 158-169.

Kalhor, B., Mehrparvar, F \& Kalhor, B. (2020). Does Using MultiDimentional Energy-Momentum Equation Change The Kinetic Energy Formula?. Independent Researcher Form Alborz, IRAN. $18 \quad$ August 2020. http://10.6084/m9.figshare.1262 $\underline{4656}$

Maison, Lestari, N \& Widaningtyas, A. (2020). Identifikasi Miskonsepsi Siswa Pada Materi Usaha dan Energi. Jurnal Penelitian Pendidikan IPA. 6(1):32-39. http://10.29303/jppipa.v6i1.314

Makhmudah, N. L., Subiki, S., \& Supeno, S. (2019). Pengembangan Modul Fisika Berbasis Kearifan Lokal Permainan Tradisional
Kalimantan Tengah Pada Materi Momentum dan Impuls. Jurnal Pembelajaran Fisika, 8(3), 181186.

Malik, Kendall. (2019). Perbedaan Nilai (Value) dan Makna (Meaning) Budaya Permainan Egrang di Empat Negara. Gorya Jurnal Seni Rupa. 8(1): 197-202. https://doi.org/10.24114/gr.v8i1. $\underline{13166}$

Martawijaya, MA. (2014). Buku Fisika Peserta Didik Berbasis Kearifan Lokal Untuk Meningkatkan Karakter dan Ketuntasan Belajar. Jurnal Sains dan Pendidikan Fisika. 10(3):285-192.

http://103.76.50.195/JSdPF/artic le/view/966

Rosita, S. M. (2019). Etnomatematka pada Rumah Adat Osing Banyuwangi sebagai Bahan Pembelajaran Matematika. [Jurusan Pendidikan MIPA Universitas Jember]. http://repository.unej.ac.id//hand le/123456789/96478

Rosramadhana, Sudirman \& Zulaini. (2020). Pemberdayaan Komunitas Remaja Melalui Inovasi Pembuatan Permainan Congkak Berbasis Digital Pada Komuunitas Permainan Di Desa Tanjung Rejo Kecamatan Percut Sei Tuan Kabupaten Deli Serdang. Jurnal Aplikasi Teknik dan Pegabdian Masyarakat. 4(2): $\quad$ 169-174. https://doi.org/10.36339/je.v4i2. $\underline{370}$

Safitri, AN., Subiki \& Wahyuni, S. (2018). Pengembangan Modul IPA Berbasis Kearifan Lokal 
Rumiati., Handayani.,\& Mahardika. - Analisis Konsep Fisika ...

Kopi pada Pokok Bahasan Usaha dan Energi Di SMP. Jurnal Pendidikan Fisika.7(1):22-29. http://dx.doi.org/10.26737/jipf.v $\underline{5 \mathrm{i} 2.1476}$

Sanjaya, W. (2010). Perencanaan dan Desain Sistem Pembelajaran. Jakarta: Kencana.

Supriyono, A. (2018). Serunya Permainan Tradisionnal Anak
Zaman Dulu. Jakarta: Badan Pengembangan dan Pembinaan Bahasa, Kementerian Pendidikan dan Kebudayaan.

Surabidin \& Djuhana. (2019). Pengaruh Massa Flywheel Terhadap Energi Kinetik, Tegangan Serta Daya Luaran Pada Flywheel Energy Storage System. Journal of Technical Engineering. 3(1): 17-23. 